\title{
Biological nitrogen removal with nitrification and denitrification via nitrite pathway
}

\author{
Yongzhen Peng • Guibing Zhu
}

Received: 1 March 2006 /Revised: 1 June 2006 / Accepted: 5 June 2006 / Published online: 7 October 2006

(C) Springer-Verlag 2006

\begin{abstract}
Presently, the wastewater treatment practices can be significantly improved through the introduction of new microbial treatment technologies. To meet increasingly stringent discharge standards, new applications and control strategies for the sustainable removal of ammonium from wastewater have to be implemented. Partial nitrification to nitrite was reported to be technically feasible and economically favorable, especially when wastewater with high ammonium concentrations or low $\mathrm{C} / \mathrm{N}$ ratios is treated. For successful implementation of the technology, the critical point is how to maintain partial nitrification of ammonium to nitrite. Partial nitrification can be obtained by selectively inhibiting nitrite oxidizing bacteria through appropriate regulation of the system's DO concentration, microbial SRT, pH, temperature, substrate concentration and load, operational and aeration pattern, and inhibitor. The review addressed the microbiology, its consequences for their
\end{abstract}

\footnotetext{
Y. Peng $\cdot$ G. Zhu $(\bowtie)$

School of Municipal and Environmental Engineering,

Harbin Institute of Technology,

Harbin 150090, China

e-mail: guibingzhu@163.com

Y. Peng

e-mail: pyz@bjut.edu.cn

G. Zhu

Research Center for Eco-Environmental Science,

China Academy of Science,

Shuangqing Road, Haidian District,

Beijing 100085, China

Y. Peng

Key Laboratory of Beijing Water Quality Science and Water

Environment Recovery Engineering,

Beijing University of Technology,

Beijing 100022, China
}

application, the current status regarding application, and the future developments.

Keywords Biological nitrogen removal · Denitrification . Partial nitrification $\cdot$ SHARON process $\cdot$ Shortcut nitrification-denitrification · Wastewater treatment

\section{Introduction}

To protect lakes and other natural water from eutrophication, stringent nutrient level is set for the effluent from the wastewater treatment plants (WWTP). Because biological nitrogen removal is effective and inexpensive, it has been adopted widely in favor of the physical-chemical processes (EPA 1993). Various novel biological nitrogen removal processes such as short-cut nitrification and denitrification, anaerobic ammonium oxidation (Anammox), completely autotrophic nitrogen removal over nitrite (Canon) process and oxygen-limited autotrophic nitrification-denitrification (Oland) process, have been developed exclusively (Verstraete and Philips 1998). However, partial nitrification is a critical procedure for implementing these novel processes owing to nitrite is required as substrate or intermediary media (Philips et al. 2002). To date, nitrification and denitrification via nitrite technology have attracted more and more interests after successful application of SHARON (Single reactor system for $H$ igh Ammonia $R$ emoval $O$ ver $N$ itrite process) in practice. Partial nitrification process is based on the fact that nitrite is an intermediary compound in both nitrification and denitrification steps: a partial nitrification up to nitrite is performed followed by nitrite denitrification (Ferhan 1996; FdzPolanco et al. 1996), as shown in Fig. 1.

Compared to the traditional nitrification and denitrification via nitrate, the main advantages of partial nitrification 
Fig. 1 Biological nitrificationdenitrification via nitrite pathway
Nitrification Denitrification

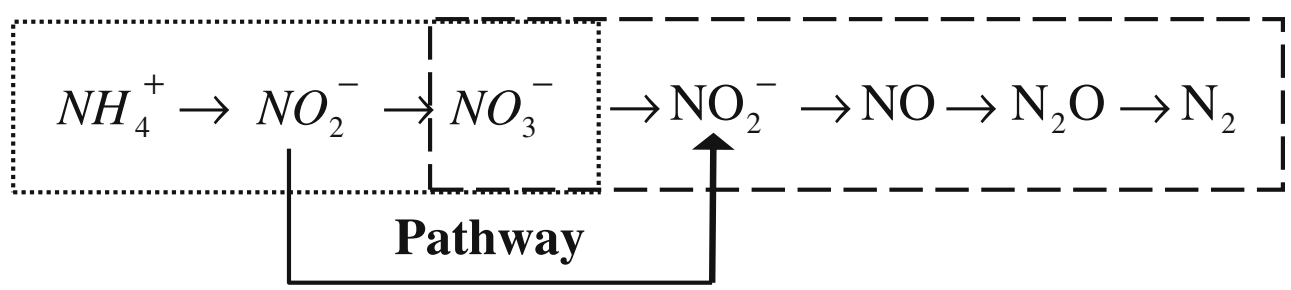

with respect to complete nitrification were reported as followed (Beccari et al. 1983; Turk and Mavinic 1987; van Kempen et al. 2001):

(1) $25 \%$ lower oxygen consumption in the aerobic stage implies $60 \%$ energy savings;

(2) in the anoxic stage the electron donor requirement is lower (up to $40 \%$ );

(3) nitrite denitrification rates are 1.5 to 2 times higher than with nitrate;

(4) reduces $\mathrm{CO}_{2}$ emission by $20 \%$;

(5) $33 \sim 35 \%$ lower sludge production in nitrification process and $55 \%$ in denitrification process.

Partial nitrification to nitrite and nitrite denitrification was reported to be technically feasible and economically favorable, especially when wastewater with high ammonium concentrations or low $\mathrm{C} / \mathrm{N}$ ratios is treated (SurmaczGorska et al. 1997; Hellinga et al. 1998). SHARON process is the first successful process in which nitrification/ denitrification with nitrite as an intermediate has been achieved under stable conditions and used in full-scale operation (Mulder et al. 2001). The full-scale application of SHARON process for nitrogen removal is shown in Table 1.

However, the operation conditions of SHARON, such as high temperature and high ammonium concentration, limit its development and application (STOWA 1995). Moreover, the application ranges mainly stage on rejection water of sludge digestion and leachate water of landfill site. How to achieve and maintain stable partial nitrification in other kinds of wastewater and in common conditions attracts more and more researchers' attention. Until now, successful partial nitrification processes recorded are obtained in sequencing operation process, and few are achieved in a continuous-flow process (Peng et al. 2003a; Khin and Annachhatre 2004). So in this review, various novel technologies for successful partial nitrification are discussed and critically reviewed. The current status regarding application and possible future research areas to further improve understanding of the process is also proposed.

\section{Biological relationships of ammonia-oxidizing bacteria and nitrite-oxidizing bacteria}

Nitrification is a sequencing biological oxidation process, which involved two different groups of bacteria. The first step of nitrification is the oxidation of ammonia to nitrite over hydroxylamine $\left(\mathrm{NH}_{2} \mathrm{OH}\right)$, involving the membranebound ammonia mono-oxygenase (AMO) and the hydroxylamine oxidoreductase (HAO), and is carried out by ammonia-oxidizing bacteria (AOB); the second group, nitrite-oxidizing bacteria (NOB), further oxidizes nitrite to nitrate. To date, any one group of bacteria that can directly oxidize ammonia to nitrate has not been found (Radajewski et al. 1994; Regan et al. 2002; Lipponen et al. 2004). Under normal conditions, the reaction of ammonia oxidation to nitrite is a velocity-limiting step; in contrast, nitrite is oxidized rapidly to nitrate, so nitrite is seldom accumulated in nitrifying reactors. In partial nitrification process, however, nitrite accumulation is required, and the second step must be restrained so as to accumulate $\mathrm{AOB}$ and washout NOB (Laanbrock and Gerards 1993).

During the nitrification process, AOB and NOB co-exist and benefit from the close physical association. On one hand, the close physical association is useful for energetic reasons: NOB are able to efficiently intercept the nitrite
Table 1 Full-scale application of SHARON process for nitrogen removal

\begin{tabular}{llllll}
\hline Full-scale plants & Capacity (pe) & Influent & N removal (\%) & $\begin{array}{l}\text { N load } \\
(\mathrm{kg} \mathrm{N} / \mathrm{d})\end{array}$ & Operational year \\
\hline Utrecht & 400,000 & Rejection water & $>95$ & 900 & 1997 \\
Rotterdam & 470,000 & Rejection water & $>95$ & 850 & 1999 \\
Zwolle & 200,000 & Rejection water & $>95$ & 410 & 2003 \\
Beverwijk & 320,000 & $\begin{array}{l}\text { Rejection water and } \\
\text { condensate }\end{array}$ & $>95$ & 1.200 & 2003 \\
Garmerwolde & 300,000 & Filtrate and condensate & $>95$ & & \\
Hague & 930,000 & Centrate & $>95$ & 2,500 & 2005 \\
& & & & 1,200 & 2005 \\
\hline
\end{tabular}


(i.e., their substrate) produced by the AOB, helping to cope with the poor energy yield of nitrite oxidation. On the other hand, AOB like the presence of the NOB, as the latter relieve them from the toxic nitrite. It therefore aids in the defense against the toxicity of nitrite by preventing its accumulation or formation of toxic by-products such as NO that can interact with bacterial enzymes (Stein and Arp 1998). But recent studies in which comparative 16S rRNA analyses of ammonia- and nitrite-oxidizing bacteria have clarified the phylogenetic relationships of these bacteria have demonstrated that they belong to two separate lineages within the Proteobacteria (Head et al. 1993; Teske et al. 1994).

The bacterial genera responsible for the oxidation of ammonia and nitrite are presumed to be predominantly the genera Nitrosomonas and Nitrobacter, both of which are chemolithoautotrophic members of the class Proteobacteria (Wheaton et al. 1994). The autotrophic ammonia-oxidizing bacteria that have been characterized belong exclusively to the $\beta$ subdivision of the Proteobacteria and are typified by Nitrosomonas europaea (Fig. 2). The SHARON process is carried out largely by Nitrosomonas eutropha (Logemann et al. 1998). These bacteria form a distinct group within the $\beta$ subdivision and are affiliated with an iron-oxidizing bacterium and the photosynthetic bacterium Rhodocyclus purpureus, along with methylotrophic bacteria. The only exception is Nitrosococcus oceanus, which is a marine species that belongs to the $\gamma$-proteobacterial lineage. The nitrite-oxidizing bacteria are more widespread in the Proteobacteria. The most commonly studied autotrophic nitrite-oxidizing bacteria belong to the á subdivision of the Proteobacteria, of which Nitrobacter winogradskyi is a representative species. Other chemolithoautotrophic nitriteoxidizing bacteria that have been characterized are phylogenetically widespread in the class Proteobacteria, occurring in the $\alpha, \delta$, and $\gamma$ subdivisions (Fig. 2).

\section{Methods and strategies for achieving and maintaining partial nitrification}

To date, researchers have developed many control methods and strategies to achieve partial nitrification. The main objective of these methods and approaches was to accumulate $\mathrm{AOB}$ and washout NOB through different activation energies, different sludge ages, different dissolved oxygen half-saturation coefficients, and different anti-toxic capacities of $\mathrm{AOB}$ and NOB. These methods mainly include appropriate regulation of the reactor system's temperature, $\mathrm{pH}$, dissolved oxygen (DO) concentration, sludge retention time (SRT), substrate concentration and load, operational and aeration pattern, inhibitor and so on (Surmacz-Gorska

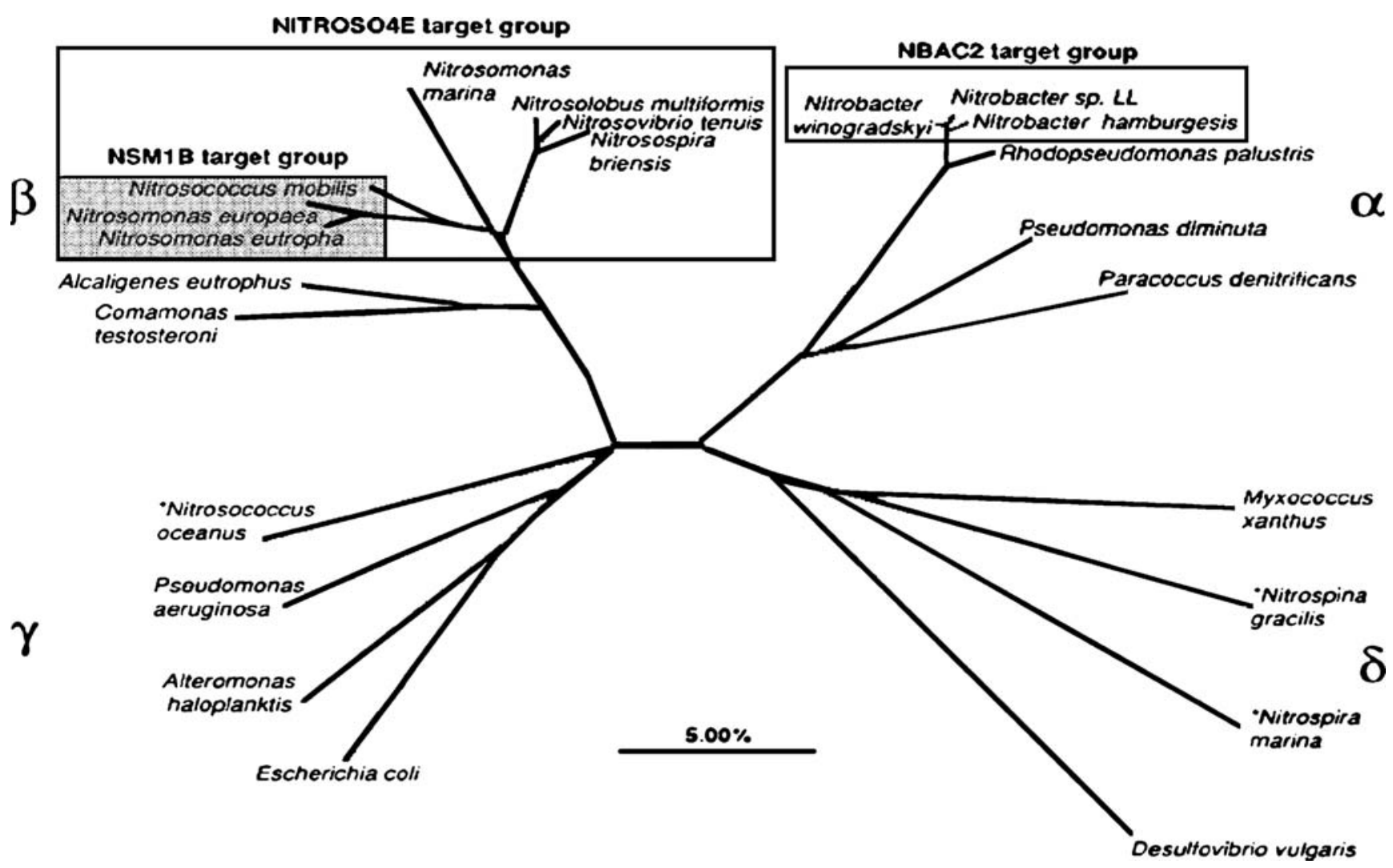

Fig. 2 Phylogenetic relationships of the chemolithoautotrophic ammonia- and nitrite-oxidizing bacteria (Timothy and Edward 1996) 
et al. 1997; van Dongen et al. 2001; López-Fiuzaa et al. 2002). Details about these approaches are discussed in the following:

\section{Reactor system's temperature}

The activation energy of two groups of bacteria and their sensitivities to temperature changing are distinctly different (Hellinga et al. 1998). So raising temperature cannot only promote the growth rates of $\mathrm{AOB}$, but can also expand the differences of specific growth rates between $\mathrm{AOB}$ and NOB, which was verified by some researchers (Yoo et al. 1999). Tonkovic (1998) noted that nitrite accumulated in an activated sludge plant especially over the summer period. There are various standpoints, however, about the optimal temperatures. Using pure cultures, optimum temperature was $35{ }^{\circ} \mathrm{C}$ for $\mathrm{AOB}$ and $38{ }^{\circ} \mathrm{C}$ for NOB (Camilla and Gunnel 2001). The SHARON process pre-mentioned was operated at $35{ }^{\circ} \mathrm{C}$ (Mulder et al. 2001). From the aspect of specific growth rate, only at temperatures above $25{ }^{\circ} \mathrm{C}$ is it possible for the ammonium oxidizers to effectively outcompete the nitrite oxidizers (Brouwer et al. 1996). But the opposite was the case at temperature below $15^{\circ} \mathrm{C}$.

Hellinga et al. (1998) have put forward the typical growth rate curves of $\mathrm{AOB}$ and $\mathrm{NOB}$ with temperature, as shown in Fig. 3. In Fig. 3, it can also be observed that the minimal residence time of $\mathrm{AOB}$ and $\mathrm{NOB}$ at temperature $>25{ }^{\circ} \mathrm{C}$ is minimal. In other words, it is not necessary to excessively elevate temperature to achieve steady partial nitrification, which is also useful to explain why optimum temperatures in the literatures were different. It is not feasible to raise temperature of wastewater for the reason of higher specific heat of water $\left(4.183 \mathrm{~kJ} \mathrm{~kg}^{-1} \mathrm{~K}^{-1}, 20{ }^{\circ} \mathrm{C}\right)$. The author suggests it is enough to keep the temperature at $25{ }^{\circ} \mathrm{C}$ when reactor system's temperature is the sole parameter. The experimental results of Yoo et al. (1999) also held out this suggestion.

\section{Sludge age}

Bock et al. (1986) have reported the minimum doubling times of $\mathrm{AOB}$ and $\mathrm{NOB}$ to be $7-8 \mathrm{~h}$ and $10-13 \mathrm{~h}$, respectively. $\mathrm{AOB}$ and washout $\mathrm{NOB}$ can be selectively accumulated by appropriate regulation sludge retention time in suspended-growth system because of different minimum required sludge ages. Based on experiences from full-scale operation, van Kempen et al. (2001) suggest to maintain SRT between 1 day and 2.5 days.

More and more literatures about successful partial nitrification were reported under long sludge age. Nitrification tests were performed by Pollice et al. $(2002 a, b)$ in two lab-scale reactors operated under continuous and intermittent aeration, respectively. The results showed that partial nitrification to nitrite were steadily obtained under oxygen limitation, independent of the sludge age of 10,14 , and 40 days. Moreover, in our laboratory successful and stable nitrite accumulations were also fulfilled to treat domestic wastewater in pilot scale $\left(54 \mathrm{~m}^{3}\right)$ and laboratory scale $\left(38\right.$ l) under normal or even low temperature $\left(<13{ }^{\circ} \mathrm{C}\right)$ with long sludge age (30 days) (Fig. 4). FISH (fluorescence in-situ hybridization) analysis results showed that AOB was the main nitrifying bacteria; no NOB was identified. The main AOB belonged to Nitrosomonas-like bacteria with PCR-DGGE. In pilot and laboratory scale experiments, the percent of AOB to total biomass is 3 and $12 \%$, respectively (Zeng et al. 2006). Contrastingly, biomass retention is not required in the SHARON process. The dilution rate is the only adjustable parameter in the SHARON process that washes out the low-growth NOB and accumulates the AOB under high temperature so as to satisfy the biomass requirement. But this approach cannot be applied successfully into continuous flow processes.

Dissolved oxygen concentration

The dissolved oxygen half-saturation coefficients of AOB and NOB are $0.2-0.4 \mathrm{mg} / \mathrm{l}$ and $1.2-1.5 \mathrm{mg} / \mathrm{l}$, respectively (Picioreanu et al. 1997). Therefore, low DO concentration is more restrictive for the growth of NOB than $\mathrm{AOB}$, which will result in nitrite accumulation (Peng et al. 2004a).

Although many researchers reported that lower DO might inhibit the growth of NOB and cause AOB accumulation, the critical values of DO recorded in the literatures were different (Laanbrock and Gerards 1993;

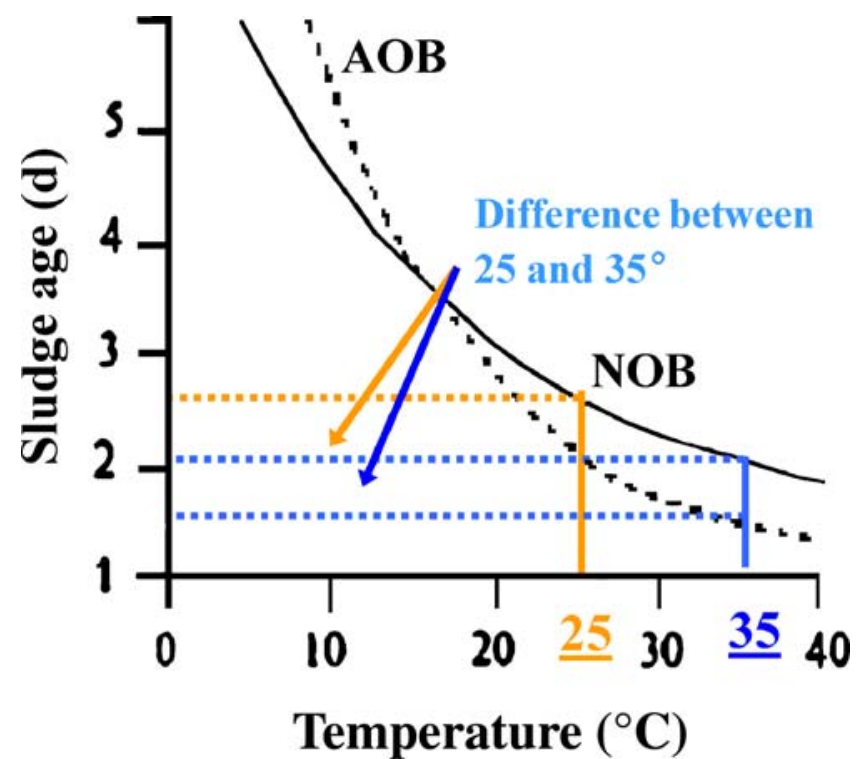

Fig. 3 Sludge age for $\mathrm{AOB}$ and $\mathrm{NOB}$ as a function of the temperature. There is little difference of minimal sludge age at temperature $>25{ }^{\circ} \mathrm{C}$. (After Hellinga et al. 1998) 
Wyffels et al. 2004). In the report of Ciudad et al. (2005), an activated sludge reactor is operated under different DO levels, analyzing nitrite accumulation and ammonia removal. Results show that at $1.4 \mathrm{mg} \mathrm{DO} / 1,75 \%$ of nitrite accumulation takes place, with $95 \%$ of ammonia removal. Moreover, nitrite accumulation shows to be stable over more than 170 days of operation. Garrido et al. (1997) found that both ammonium oxidation rate and nitrite accumulation reached maximum when DO was $1.5 \mathrm{mg} / \mathrm{l}$. Below $0.5 \mathrm{mg} / \mathrm{l}$ of DO ammonium was accumulated and over $1.7 \mathrm{mg} / \mathrm{l}$ complete nitrification to nitrate was achieved (Ruiz et al. 2003). On the other hand, it should be noticed that lower DO will lower nitrification rate and cause filamentous bulking sludge. Considering ammonia oxidation rate and nitrite accumulation, DO concentration should be maintained about $1.0-1.5 \mathrm{mg} / \mathrm{l}$. It is a good idea to use real-time control methods to regulate DO concentration in the reactor. There is often appearance of "ammonia break point" in the DO profiles, and "ammonia valley" in the $\mathrm{pH}$ profiles at the end of nitrification for SBR process, shown in Fig. 5 (Wang et al. 2004). So the nitritation process can well be predominated by identifying "ammonia valley" and "ammonia break point" and avoiding from high DO and excess aeration.

Operational and aeration pattern

The aeration pattern is proposed as an alternative parameter to control ammonium oxidation to nitrite (Hidaka et al. 2002). Duration of aeration time was found to be inversely related to the degree of nitrite build-up (Turk and Mavinic 1987). Using of intermittent aeration was in favor of implementation of nitrite accumulation (Pollice et al. 2002a,b). Also, the continuous feeding of the influent wastewater from the bottom of the reactor was critical for effective nitrification and denitrification via nitrite (Yoo et al. 1999). As the induction of the different denitrification enzymes proceeds sequentially, the different intermediates of denitrification accumulate temporarily after the switch from aerobic to anoxic conditions. The length of the anoxic period is, therefore, important to achieve complete denitrification. According to Baumann et al. (1997), an anoxic period of $4 \mathrm{~h}$ is sufficient to synthesize all enzymes and have complete denitrification. Besides, Peng et al. (2004a) reported that using aeration control strategy partial nitrification had been achieved, although the temperature was decreased from 32 to $21{ }^{\circ} \mathrm{C}$.

Many researchers have been working on SBR control based on common sensors such as $\mathrm{pH}$ measurements that should be easy to install with a little additional investment (Al-Ghusain and Hao 1995). The $\mathrm{pH}$ value decreases during the aeration period due to alkalinity consumption by nitrification. Theoretically, $\mathrm{pH}$ value in the course of converting nitrite to nitrate should not vary because there is no hydrogen ion produced, which is contrary to the process of ammonia conversion to nitrite. But when both nitritation and nitratation are completed, $\mathrm{pH}$ will increase because of $\mathrm{CO}_{2}$ stripping. So there would be an inflexion of $\mathrm{pH}$ value in the liquid phase at the end of nitrification, as shown in Fig. 6. Stable partial nitrification can be achieved by online control technology, with variations of characteristic features and the differential coefficient as input variable parameters, thus preventing from excess aeration (Peng et al. 2003b). Long-time operation with online control strategy would result in AOB accumulating and NOB washout, which is a course of AOB community optimization.

$\mathrm{pH}$

The value of $\mathrm{pH}$ influences partial nitrification in the following several aspects:

\section{Influence on free ammonia (FA)}

Free ammonia (FA) is a competitive inhibitor of nitrite oxidoreductase activity, which is located on the cell membrane of NOB (Yang and Alleman 1992). The inhibitions of free ammonia to two groups of bacteria are
Fig. 4 In situ identification of nutrifying bacteria from pilotscale SBR a and lab-scale SBR b a and b: Green for activated sludge (FITC labeled probe $\left.\mathrm{EUB}_{\text {mix }}\right)$ and red for AOB $\beta$ Proteobacteria (CY3 labeled probe NSO 1225) (Zeng et al. 2006)
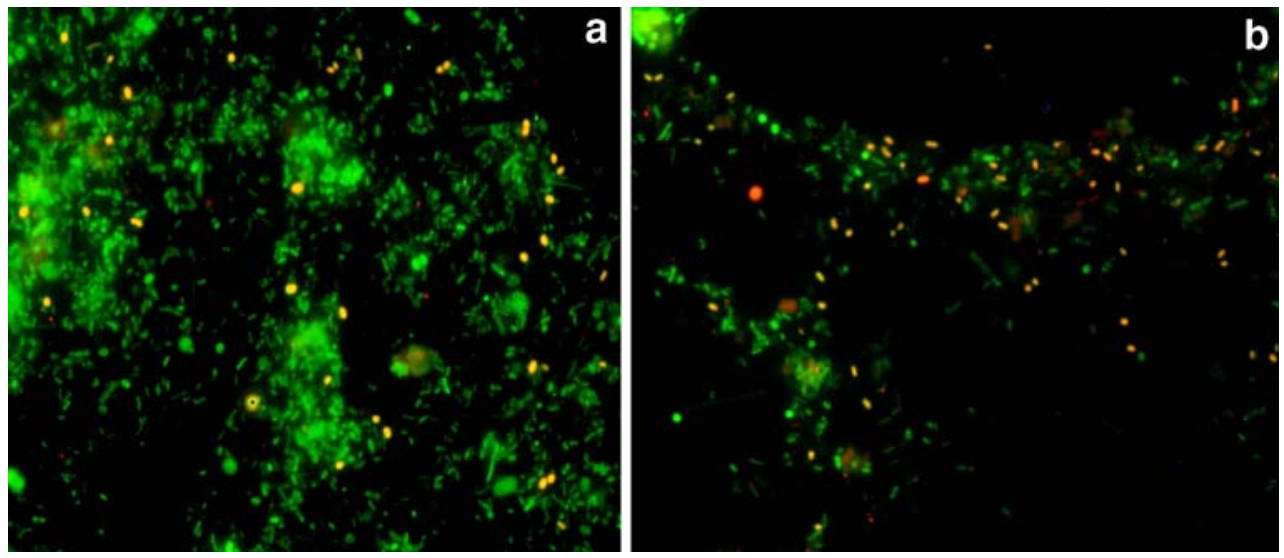
Fig. 5 The typical variations of $\mathrm{DO}$ and $\mathrm{pH}$ for organic substrate removal and nitrification process in SBR process

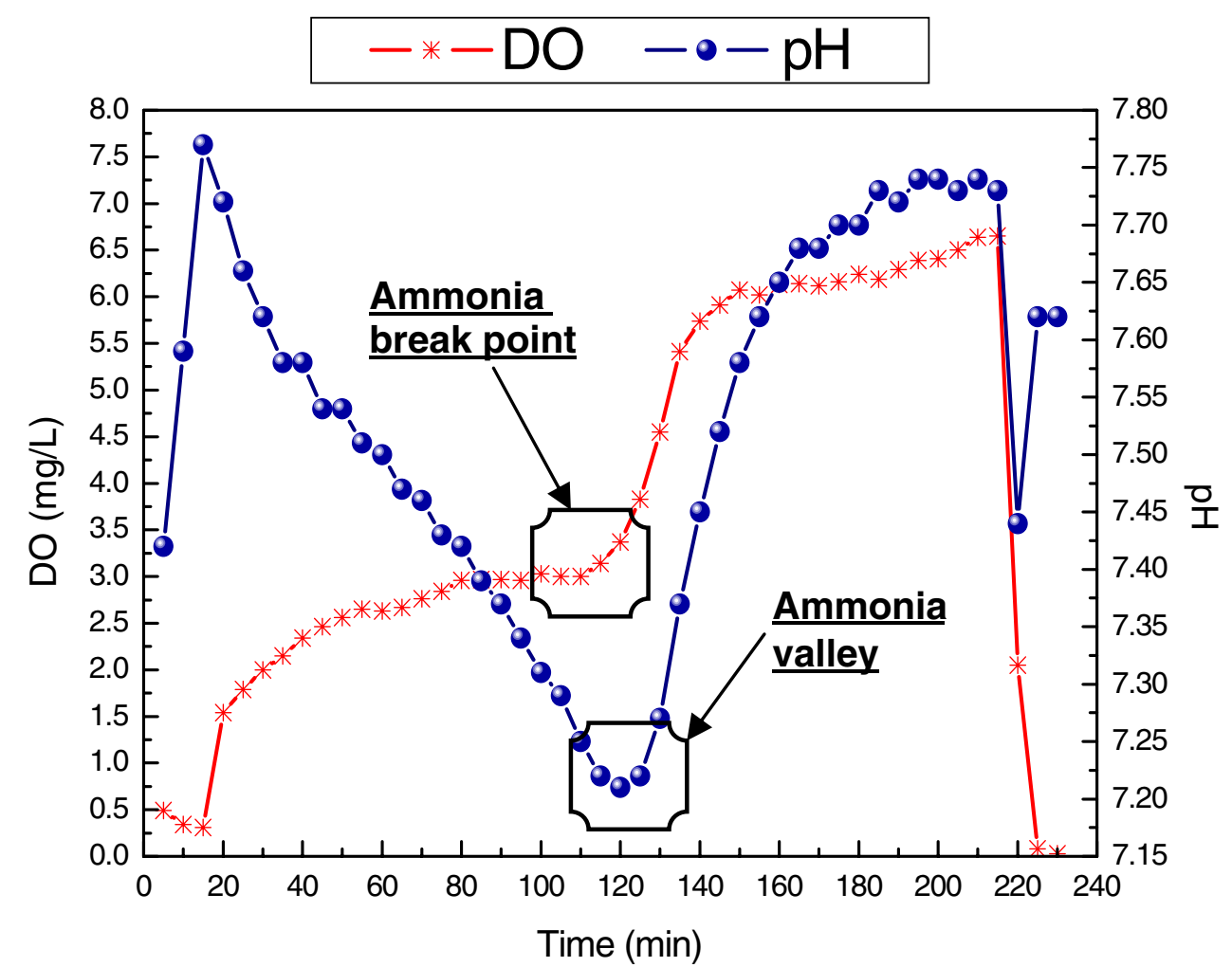

different, and the relationship between free-ammonia concentration and $\mathrm{pH}$ is as follows (Anthonisen 1976):

$\mathrm{FA}=\frac{17}{14} \times \frac{\left[\mathrm{NH}_{4}^{+}-\mathrm{N}\right] 10^{\mathrm{pH}}}{K_{a} / K_{W} \quad 10^{\mathrm{pH}}}$
Here, FA is free-ammonia concentration, $\left[\mathrm{NH}_{4}{ }^{+}-\mathrm{N}\right]$ is ammonium concentration, $K_{\mathrm{a}}$ and $K_{\mathrm{w}}$ are ionization constants of ammonia and water, respectively. Boundary conditions for FA inhibition of both $\mathrm{AOB}$ and $\mathrm{NOB}$ were first depicted in Anthonisen (1976) (Fig. 7).
Fig. 6 Typical variations of $\mathrm{DO}, \mathrm{pH}$, and ORP value and concentrations of ammonia, nitrite, and nitrate during nitrification and denitrification process in SBR (Yang et al. 2006) Influent $\mathrm{NH}_{4}=56 \mathrm{mg} / \mathrm{l}$; $\mathrm{COD}=254 \mathrm{mg} / \mathrm{l}$ alkalinity $=268 \mathrm{mg} / 1$

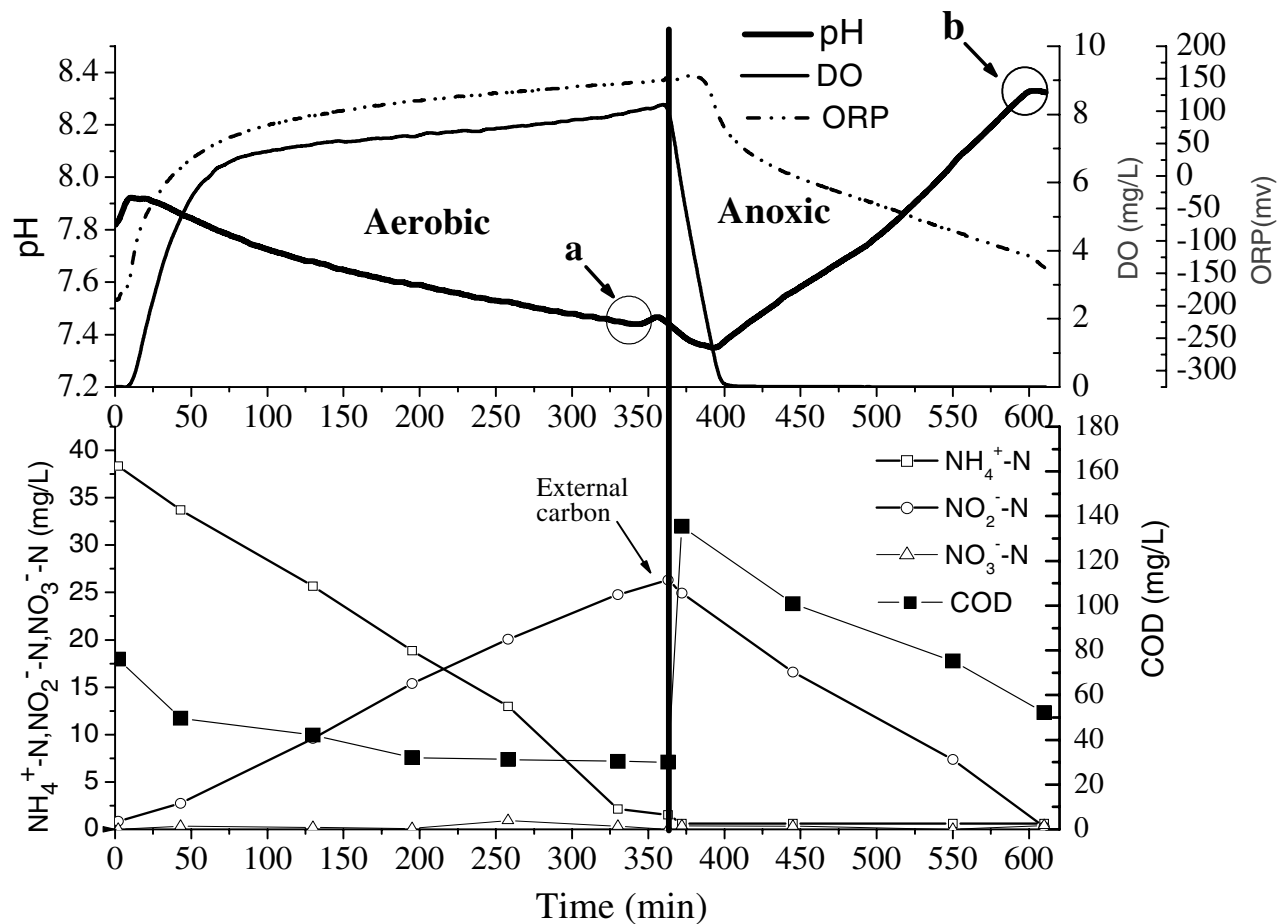




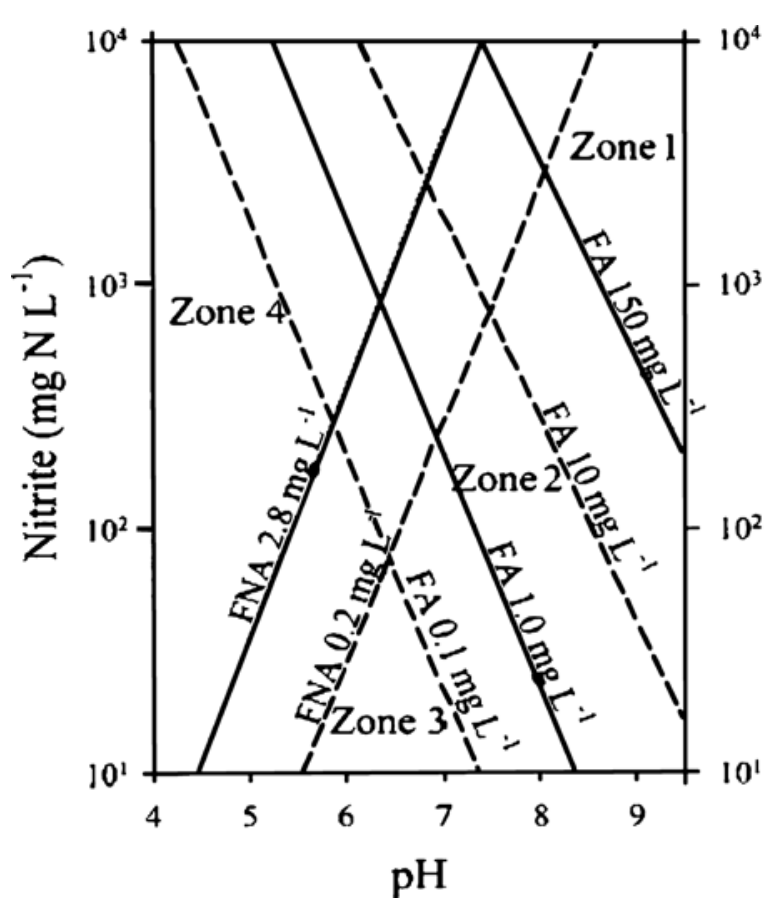

Fig. 7 Relationship between concentrations of free ammonia $(F A)$ and free nitrous acid $(F N A)$ and inhibition to nitrifiers. The dashed lines mark the lower limit and the solid lines mark the upper limit of the range of boundary conditions of zones of nitrification inhibition. Zone $1=$ inhibition of nitritation and nitratation by $F A$; Zone $2=$ inhibition of nitratation by $F A$; Zone $3=$ complete nitrification; Zone $4=$ inhibition of nitratation by FNA (Anthonisen et al. 1976)

Many researchers confirmed that nitrite accumulation could be achieved by regulating $\mathrm{pH}$ to control freeammonia concentration (Ferhan 1996; Peng et al. 2004b). At $\mathrm{FA} \geq 7 \mathrm{mg} \mathrm{NH}-\mathrm{N} / \mathrm{l}$, ammonia oxidation reaction is inhibited, and ammonia oxidation reaction will almost cease at $20 \mathrm{mg} \mathrm{NH}-\mathrm{N} / 1$ (Abeling and Seyfried 1992). But the threshold inhibition concentrations of free ammonia found in the literature were different. It was reported that the system could stably operate at freeammonia concentration of $50 \mathrm{mg} \mathrm{NH} \mathrm{NH}_{3}-\mathrm{N} / \mathrm{l}$, but nitrite oxidation activity would be inhibited in the presence of free-ammonia concentration higher than $3.5 \mathrm{mg} \mathrm{NH} \mathrm{NH}_{3}$ N/1 (Wong-Chong and Loehr 1978). Free ammonia has only an inhibition effect on NOB, but does not kill them. After a period of cultivation, NOB will recover activity (Beccari et al. 1983; Han et al. 2003). It is necessary to synthetically consider other factors to achieve stable partial nitrification when only by regulating free-ammonia concentration (Fdz-Polanco et al. 1994; SurmaczGorska et al. 1997). Ford et al. (1980) reported that both ammonia and nitrite oxidation activities would be inhibited under the condition of free-ammonia concentration higher than $24 \mathrm{mg} \mathrm{NH}-\mathrm{N} / \mathrm{l}$, but they would recover as soon as free-ammonia concentration was below the threshold concentration, and the system could operate in spite of free-ammonia concentration of $56 \mathrm{mg}$ $\mathrm{NH}_{3}-\mathrm{N} / 1$

\section{Influence on $\mathrm{HNO}_{2}$}

The research results suggested that an $\mathrm{HNO}_{2}$ concentration of $0.13 \mathrm{mg} / \mathrm{l}$ was proposed as the toxicity threshold for nitrite to denitrifying bacteria (Abeling and Seyfried 1992). An inhibition mechanism that has been proposed for $\mathrm{HNO}_{2}$ toxicity is that it acts as an uncoupler by donating a proton inside the cell. That intracellular proton directly interferes with the transmembrane $\mathrm{pH}$ gradient required for ATP synthesis (Glass et al. 1997).

The $\mathrm{pH}$ regulates the equilibrium between nitrite and nitrous acid. The relationship between $\mathrm{HNO}_{2}$ distribute ratio and $\mathrm{pH}$ is as follows:

$$
\mathrm{HNO}_{2} / \%=\frac{100}{1+\left[K_{\mathrm{b}}\right] / 10^{-\mathrm{pH}}}
$$

$\left[K_{\mathrm{b}}\right]$ is ionization constant of nitrous acid

Furthermore, $\mathrm{pH}$ values $>7$ have the double effect of limiting the conversion of nitrite into nitrous acid and ensuring concentrations of free ammonia that would selectively inhibit nitrite oxidizers, thus favoring the stability of partial nitrification.

In addition to higher organisms like human being, nitrite has also a known influence upon micro-organisms and their processes. It is a known bacteriostatic molecule due to its affinity for the metal ions in the center of enzymes (Wild et al. 1995). According to Sijbesma et al. (1996), nitrite acts as a protonophore that stimulates basal electron transport, inhibits ATP (adenosine triphosphate) synthesis, stimulates ATP hydrolysis, and inhibits various exchange reactions catalysed by the ATP-ase (Rottenberg 1990). The inhibition effects by nitrite of ammonia oxidation activity are shown in Fig. 8.

\section{Influence on free-hydroxylamine (FH) concentration}

The presence of free hydroxylamine, a toxic intermediate in nitrification by $\mathrm{AOB}$, appeared to have a consistent correlation with low nitrification activity (Castignetti and Gunner 1982; Stüven et al. 1992). According to $\mathrm{Hu}$ (1990), hydroxylamine exhibited acute toxicity to NOB, and this may also cause nitrite build-up in a nitrifying system. No nitrite oxidation occurred when $0.42 \mathrm{mgNH}_{2} \mathrm{OH}-\mathrm{N} / 1$ was present. Addition of $2.5-5 \mathrm{mgNH}_{2} \mathrm{OH}-\mathrm{N} / 1$ to a submerged filter system significantly enhanced nitrite accumulation during nitrification (Hao and Chen 1994). Moreover, this inhibitory effect of hydroxylamine on NOB was found to 


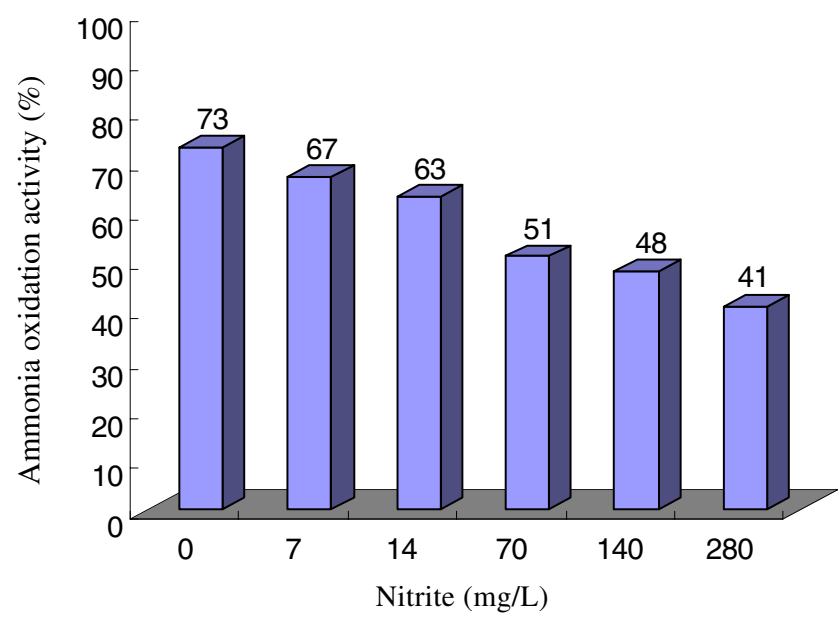

Fig. 8 Ammonia-oxidizing activity relative to the initial activity in Nitrosomonas europaea cells exposed to nitrite after a 24-h incubation $(\mathrm{pH} 8)$ in the absence of ammonium under aerobic conditions (after Stein and Arp 1998)

be irreversible. Hydroxylamine appeared likely to accumulate in a nitrifying system with high $\mathrm{NH}_{3} / \mathrm{NH}_{4}{ }^{+}$concentration, deficient oxygen, and high $\mathrm{pH}$ (Stüven et al. 1992).

\section{Control of substrate concentration and load}

Research results showed that AOB could be divided into two different groups of bacteria: slow-growth and fastgrowth pattern (Zheng et al. 2004). One group of ammonia oxidation bacteria (fast-growth pattern) has higher affinity for substrate ammonia (lower half-saturation coefficient for ammonia) and thus can grow under the condition of lowsubstrate concentration with the higher specific growth rate. Oppositely, another has lower affinity for substrate and can only grow under the condition of high substrate concentration. The curve growth rates of two types of AOB vs substrate concentration were shown in Fig. 9. In conventional wastewater treatment process, ammonia concentration generally would be controlled at the lower level to satisfy discharge standard. However, fast-growth-pattern AOB will accumulate in partial nitrification reactors because of high ammonia concentration (Surmacz-Gorska et al. 1997). These also demonstrate why it is easy to achieve partial nitrification to treat wastewater with high concentrations of ammonia, but difficult to implement and maintain steady partial nitrification with treatment of common domestic wastewater (Sliegrist et al. 1998; van Dongen et al. 2001).

Moreover, in the case of nitrification, according to Okabe et al. (1996), a higher $\mathrm{C} / \mathrm{N}$ ratio retarded an accumulation of nitrifying bacteria, particularly NOB. Due to competition for common electron donors, nitrate in high concentrations has been found to inhibit the nitrite reduction (Almeida et al. 1995; van Rijn et al. 1996). In addition, Kornaros et al. (1996) found that nitrate has an

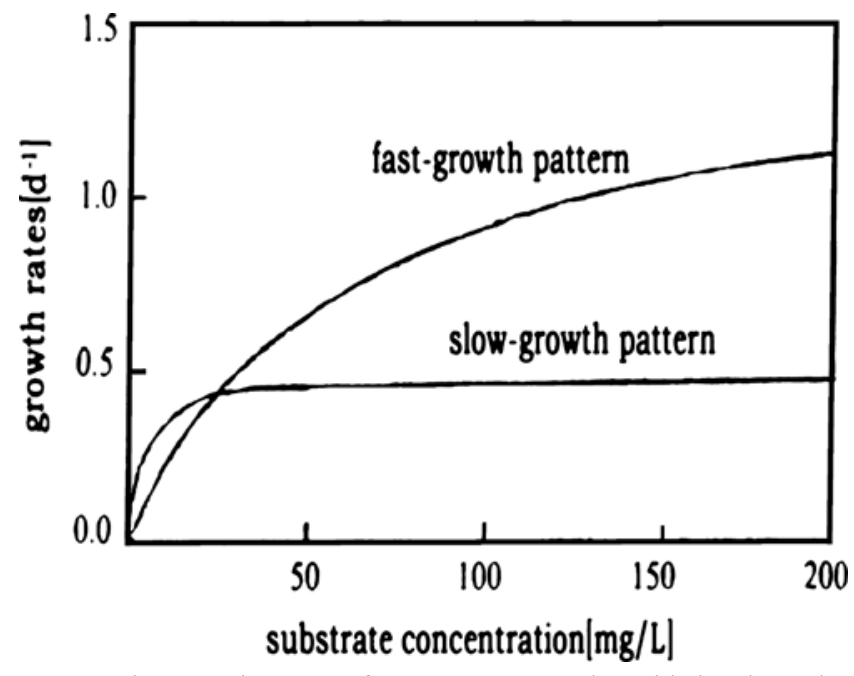

Fig. 9 The growth curve of two type ammonia oxidation bacteria. The substrate was the common limiting growth factors such as ammonia and DO. (Zheng et al. 2004)

inhibitory effect on the synthesis and activity of nitrite reductase. During dissimilatory nitrate reduction to ammonium, nitrite accumulates especially when high concentrations of nitrate resulted from inhibition of the nitrite reductase system by nitrate, $140 \mathrm{mg} \mathrm{NO}-\mathrm{N} / 1$ are present (Bonin 1996).

Experimental results of Nowak have shown that nitrite oxidation might be affected by phosphorus deficiency, the so-called phosphate block (Nowak et al. 1996). The phosphate half-saturation coefficient for NOB $(0.2 \mathrm{mg}$ P/l) is about one order of magnitude higher than for $\mathrm{AOB}$ (0.03 mg P/l) (Nowak et al. 1996). The nitrite oxidation was substantially reduced at phosphate levels below $0.2 \mathrm{mg}$ $\mathrm{PO}_{4}{ }^{3}$-P/l. In this case, the presence of phosphate, rather than its absence, has also a profound effect on denitrification and causes nitrite accumulation. Nitrite reduction rate decreased from 4.9 to $2.7 \mathrm{mg} \mathrm{NO}-\mathrm{N} / \mathrm{g}$ protein min as phosphate concentration was increased from 0 to $15.5 \mathrm{mg}$ $\mathrm{P} / 1$ (Barak et al. 2000).

\section{Inhibitor}

The inhibitors for nitrification include heavy metal, toxicant, organic compounds, fulvic acids, oxidants, volatile fatty acids, and halide (Garrido 1998; Zhang et al. 2000; López-Fiuzaa et al. 2002). Heavy metals, chromium, nickel, copper, zinc, lead, and cadmium, might inhibit both steps of nitrification reaction, but the inhibition effects are different (Camilla et al. 1998). The ranges of metal concentrations of inhibition to nitrification under pure culture were shown in Table 2. No other metals were shown to be significantly inhibiting.

Nitrite accumulation in the biofilm process was related to fulvic acids loadings. When the fulvic acids loading was 
Table 2 Ranges of metal concentrations of inhibition to nitrification (Camilla et al. 1998)

\begin{tabular}{ll}
\hline Metal & Concentration $(\mu \mathrm{g} / 1)$ \\
\hline $\mathrm{Cr}$ & $0.7-785$ \\
$\mathrm{Ni}$ & $3-860$ \\
$\mathrm{Cu}$ & $3-5,730$ \\
$\mathrm{Zn}$ & $3-1,000$ \\
$\mathrm{~Pb}$ & $0.09-1,680$ \\
$\mathrm{Cd}$ & $0.01-20$ \\
\hline
\end{tabular}

less than $0.002 \mathrm{~kg}(\mathrm{TOC}) / \mathrm{m}^{3} \mathrm{~h}$, no nitrite build-up appeared, but when the loading was in the range of $0.002 \pm 0.02 \mathrm{~kg}$ (TOC) $/ \mathrm{m}^{3} \mathrm{~h}$, nitrite built up and the concentration of nitrite could reach as high as $11.4 \mathrm{mg} / \mathrm{l}$. When the loading was above $0.07 \mathrm{~kg}$ (TOC) $/ \mathrm{m}^{3} \mathrm{~h}$, the nitrification process was completely inhibited (Zhang et al. 2000). Organic compounds such as aniline, ortho-cresol, and phenol have stronger inhibition influences on NOB than on $\mathrm{AOB}$, so biological wastewater treatment with these organics might cause nitrite accumulation phenomenon (Neufeld et al. 1986) to occur.

Oxidants such as chlorite and chlorate have inhibition effect on NOB. The inhibition effect of chlorite and chlorate is selective, which is different with other inhibitors (Belser and Mays 1980). The growth of NOB would be inhibited when the concentration of potassium chlorate was during $0.001-0.01 \mathrm{mM}$. When the concentration of $\mathrm{ClO}_{3}$ is $1-10 \mathrm{mM}$, the activity of NOB would be inhibited completely, and when the concentration of $\mathrm{ClO}_{2}$ is $3 \mathrm{mM}$, it would also be the case. The real inhibitor to nitrite oxidation bacteria was verified to be $\mathrm{ClO}_{2}$. The results proposed by Belser and Mays (1980) demonstrated that the concentration $\mathrm{ClO}_{3}$ of $10 \mathrm{mM}$ had no effects on the activity of $\mathrm{AOB}$; in other words, ammonia oxidation rate would be fully identical with the rate without $\mathrm{ClO}_{3}$ addition, but the activity of NOB was inhibited completely (Lees and Quastel 1945).

Volatile fatty acids, formic, acetic, propionic and $n$ butyric acid all inhibited nitrite oxidation, but exhibited no significant effect on ammonia oxidation (Eilersen et al.
1994). Eilersen et al. (1995) provided the critical concentrations of volatile fatty acids in Table 3 , which is the concentration at which activity falls to $50 \%$ of the activity in the absence of the inhibiting compound.

$\mathrm{Cl}_{2}$ and $\mathrm{Br}_{2}$ as disinfectors used commonly in water treatment would also inhibit NOB (Cotteux and Duchene 2003; Peng et al. 2004c). The experimental results from biological treatment of wastewater containing seawater indicated that salinity had benefits to nitrite accumulation (Peng et al. 2005). When the ratio of seawater to wastewater was $30 \%$, and the ammonia loading was below the critical value of $0.15 \mathrm{kgNH}_{4}{ }^{+}-\mathrm{N} /(\operatorname{kgMLSS} . \mathrm{d})$, the ammonia removal efficiency via nitrite pathway was above $90 \%$.

\section{Critical review on various control technologies}

By comparing and evaluating steady nitrification and denitrification via nitrite pathway used in practical application, the most successful implementation was obtained in sequencing operation process. Few were achieved in continuous-flow process, also not in domestic wastewater with influent $\mathrm{NH}_{4}{ }^{+}-\mathrm{N}<50 \mathrm{mg} / \mathrm{l}$. Moreover, how to accomplish partial nitrification in continuous flow systems has some problems to solve, as nitrite concentration in the effluent is equal to nitrite concentration recycled. How to implement stable partial nitrification process in the treatment of common domestic wastewater with continuousflow system should be the future research direction. Besides, partial nitrification process can be achieved by inhibiting NOB growth with FA and chlorate. But chlorates only have irreversible inhibition on NOB, not AOB. Moreover, the effect mechanisms of FA and inhibitors are different, which FA only selectively inactivated, but inhibitors selectively deaden NOB. Consequently, this aspect should be researched in-depth. Stable partial nitrification can also be fulfilled under normal or long sludge age condition, which is contrary to the SHARON process. The on-line measurement and control technology with DO and $\mathrm{pH}$ and their differential coefficient as input variable parameters would be a feasible research direction. With
Table 3 Critical concentrations $(\mathrm{mM})$ of some volatile fatty acids with respect to inhibition of nitrification and denitrification (Eilersen et al. 1994, 1995)

\begin{tabular}{lllll}
\hline Volatile fatty acid & Ammonia oxidation & Nitrite oxidation & Nitrite reduction & Nitrate reduction \\
\hline Formic acid & - & 2 & - & - \\
Acetic acid & - & 115 & - & - \\
Propionic acid & - & 68 & 196 & 74 \\
$n$-Butyric acid & - & 33 & - & - \\
Isobutyric acid & 6 & 8 & 32 & 30 \\
$n$-Valeric acid & 37 & 75 & 57 & 36 \\
Isovaleric acid & 6 & 7 & 18 & 18 \\
$n$-Caproic acid & 36 & 81 & 110 & 105 \\
\hline
\end{tabular}


this technology, stable partial nitrification can be fulfilled and applied in the treatment of common municipal wastewater other than high-ammonia wastewater, which is the most distinct advantage over other methods and approaches.

\section{Conclusions}

Biological nitrification and denitrification via nitrite pathway is technically feasible and economically favorable, especially when wastewater with high ammonium concentrations or low $\mathrm{C} / \mathrm{N}$ ratios is treated. The paper reviewed the biological relationships of ammonia-oxidizing bacteria and nitrite-oxidizing bacteria. Moreover, the review extensively discussed the factors and estimated all methods used to achieve steady partial nitrification. By discussing and analyzing impact factors, it is possible to implement steady nitrite accumulation only through regulating one of the factors. DO concentration is an economically feasible control parameter. Under the condition of lower DO concentration, the aeration will be saved, but it is possible to reduce COD biodegradation rate and cause filamentous bulking sludge. Furthermore, idiographic and practical conditions should be considered, too. For example, it is unpractical to raise temperature for treating common municipal wastewater, because of higher water-specific heat. It is necessary to consider economic feasibility when using temperature, $\mathrm{pH}$, and inhibitor as regulation parameter. But based on the fact that the influence mechanisms of some parameters have not been confirmed and the interrelations among some other parameters possibly exist, such as $\mathrm{pH}$ and substrate concentration and FA concentration, it is necessary to detailedly and roundly consider these factors.

Acknowledgements This research is financially supported by the National Natural Science Foundation Key International Cooperation project of China (No. 50521140075), National Hi-Tech Development Program "863" project (No. 2004AA601020), and the National Natural Science Foundation (20377003). Give special thanks to Mr. Guo Jianhua for his help in English checking.

\section{References}

Abeling U, Seyfried CF (1992) Anaerobic-aerobic treatment of high strength ammonium wastewater nitrogen removal via nitrite. Water Sci Technol 26:1007-1015

Al-Ghusain IA, Hao OJ (1995) Use of $\mathrm{pH}$ as control parameter for aerobic/anaerobic sludge digestion. J Environ Eng 121(3): 225-235

Almeida JS, Reis MAM, Carrondo MJT (1995) Competition between nitrate and nitrite reduction in denitrification by Pseudomonas fluorescens. Biotechnol Bioeng 46(5):476-484

Anthonisen AC (1976) Inhibition of nitrification by ammonia and nitrous acid. J Water Pollut Control Fed 48(5):835-852
Barak Y, Tal Y, van Rijn J (2000) Relationship between nitrite reduction and active phosphate uptake in the phosphate accumulating dentrifier Pseudomonas sp. strain JR 12. Appl Environ Microbiol 66(12):5236-5240

Baumann B, Snozzi M, Van der Meer JR, Zehder AJB (1997) Development of stable denitrifying cultures during repeated aerobic-anaerobic transient periods. Water Res 31:1947-1954

Beccari M, Marani E, Ramadori R, Tandoi V (1983) Kinetic of dissimilatory nitrate and nitrite reduction in suspended growth culture. J Water Pollut Control Fed 55:58-64

Belser LW, Mays EL (1980) Specific inhibition of nitrite oxidation by chlorate and its use in assessing nitrification in soils and sediments. Appl Environ Microbiol 39:505-510

Bock E, Koops HP, Harms H (1986) Cell biology of nitrifying bacteria. In: Prosser JI (ed) Nitrification. IRL, Oxford, pp 17-38

Bonin P (1996) Anaerobic nitrate reduction to ammonium in two strains isolated from coastal marine sediment: a dissimilatory pathway. FEMS Microbiol Ecol 19(1):27-38

Brouwer M, van Loosdrecht MCM, Heijnen JJ (1996) One reactor system for ammonium removal via nitrite. STOWA Report. 9601. STOWA, Utrecht, The Netherlands. (ISBN 907447655 4)

Camilla G, Gunnel D (2001) Development of nitrification inhibition assays using pure cultures of Nitrosomonas and Nitrobacter. Water Res 35(2):433-440

Camilla G, Lena G, Gunnel D (1998) Comparison of inhibition assays using nitrogen removing bacteria: application to industrial wastewater. Water Res 32(10):2995-3000

Castignetti D, Gunner HB (1982) Differential tolerance of hydroxylamine by an Alcaligenes sp., a heterotrophic nitrifier, and by Nitrobacter agilis. Can J Microbiol 28:148-150

Ciudad G, Rubilar O, Muòoz P, Ruiz G, Chamy R, Vergara C, Jeison D (2005) Partial nitrification of high ammonia concentration wastewater as a part of a shortcut biological nitrogen removal process. Process Biochem 40:1715-1719

Cotteux E, Duchene P (2003) Nitrification preservation in activated sludge during curative bulking chlorination. Water Sci Technol 47(11):85-92

Eilersen AM, Henze M, Kloft L (1994) Effect of volatile fatty acids and trimethylamine on nitrification in activated sludge. Water Res 28(6):1329-1336

Eilersen AM, Henze M, Kloft L (1995) Effect of volatile fatty acids and trimethylamine on denitrification in activated sludge. Water Res 29(5):1259-1266

EPA (1993) Process design manual for nitrogen control. US EPA, Washington, DC

Fdz-Polanco F, Villaverde S, Garcia PA (1994) Temperature effect on nitrifying bacteria activity in biofilters: activation and free ammonia inhibition. Water Sci Technol 30(11):121-130

Fdz-Polanco F, Villaverde S, Garcia PA (1996) Nitrite accumulation in submerged biofilters-combined effects. Water Sci Technol 34 (3-4):371-378

Ferhan C (1996) Investigation of partial and full nitrification characteristics of fertilizer wastewaters in a submerged biofilm reactor. Water Sci Technol 34(11):77-85

Ford DL, Churchwel RL, Kachtick JW (1980) Comprehensive analysis of nitrification of chemical processing wastewaters. J Water Pollut Control Fed 52:2726-2746

Garrido JM (1998) Nitrous oxide production under toxic conditions in a denitrifying anoxic filter. Water Res 32(8):2550-2552

Garrido JM, van Benthem W, van Loosdrecht MCM, Heijnen JJ (1997) Influence of dissolved oxygen concentration on nitrite accumulation in a biofilm airlift suspension reactor. Biotechnol Bioeng 53:168-178

Glass C, Silverstein J, Oh J (1997) Inhibition of denitrification in activated sludge by nitrite. Water Environ Res 69(6): 1086-1093 
Han DW, Chang JS, Kim DJ (2003) Nitrifying microbial community analysis of nitrite accumulating biofilm reactor by fluorescence in situ hybridization. Water Sci Technol 47(1):97-104

Hao OJ, Chen JM (1994) Factors affecting nitrite buildup in submerged filter system. J Environ Eng 120(5):1298-1307

Head IM, Hiorns WD, Embley TM, McCarthy AJ, Saunders JR (1993) The phylogeny of autotrophic ammonia-oxidizing bacteria as determined by analysis of $16 \mathrm{~S}$ ribosomal RNA genesequences. J Gen Microbiol 139:1147-1153

Hellinga C, Schellen AAJC, Mulder JW, van Loosdrecht MCM, Heijnen JJ (1998) The SHARON process: an innovative method for nitrogen removal from ammonium-rich wastewater. Water Sci Technol 37(9):135-142

Hidaka T, Yamada H, Kawamura M, Tsuno H (2002) Effect of dissolved oxygen conditions on nitrogen removal in continuously fed intermittent-aeration process with two tanks. Water Sci Technol 45:181-188

Hu SS (1990) Acute substrate-intermediate-product related inhibition of nitrifiers. M.S. Thesis. School of Civil Engineering, Purdue University, West Lafayette, Indiana, USA

Khin Than, Annachhatre Ajit P (2004) Novel microbial nitrogen removal processes. Biotechnol Adv 22:519-532

Kornaros M, Zafiri C, Lyberatos G (1996) Kinetics of denitrification by Pseudomonas denitrificans under growth conditions limited by carbon and/or nitrate or nitrite. Water Environ Res 68:934-945

Laanbrock HJ, Gerards S (1993) Competition for limiting amounts of oxygen between Nitrosomonas europaea and Nitrobacter winogradsky grown in mixed continuous cultures. Arch Microbiol 159:453-459

Lees H, Quastel JH (1945) Bacteriostatic effects of potassium chlorate on soil nitrification. Nature 155:276-278

Lipponen MTT, Martikainen PJ, Vasara RE, Servomaa K, Zacheus O, Kontro MH (2004) Occurrence of nitrifiers and diversity of ammonia-oxidizing bacteria in developing drinking water biofilms. Water Res 38:4424-4434

Logemann S, Schantle J, Bijvank S, van Loosdrecht M, Kuenen JG, Jetten M (1998) Molecular microbial diversity in a nitrifying reactor system without sludge retention. FEMS Microbiol Ecol 27:239-249

López-Fiuzaa J, Buysb B, Mosquera-Corrala A, Omil CF, Méndeza R (2002) Toxic effects exerted on methanogenic, nitrifying and denitrifying bacteria by chemicals used in a milk analysis laboratory. Enzyme Microb Technol 31(7):976-985

Mulder JW, van Loosdrecht MCM, Hellinga C, van Kempen R (2001) Full-scale application of the SHARON process for the treatment of rejection water of digested sludge dewatering. Water Sci Technol 43(11):127-134

Neufeld R, Greenfield J, Rieder B (1986) Temperature, cyanide and phenolic nitrification inhibition. Water Res 20(5):633-642

Nowak O, Svardal K, Kroiss H (1996) The impact of phosphorus deficiency on nitrification-case study of a biological pretreatment plant for rendering plant effluent. Water Sci Technol 34 (1-2):229-236

Okabe S, Ozawa Y, Hirata K, Watanabe Y (1996) Relationship between population dynamics of nitrifiers in biofilms and reactor performance at various C:N ratios. Water Res 30 (7):1563-1577

Peng YZ, Chen T, Tian WJ (2003a) Nitrogen removal via nitrite at normal temperature in A/O process. J Environ Sci Health, Part A, Environ Sci Eng 39(7):1667-1680

Peng YZ, Gao JF, Wang SY, Sui MH (2003b) Use of pH as fuzzy control parameter for nitrification under different alkalinity in SBR process. Water Sci Technol 47(11):77-85

Peng YZ, Chen Y, Peng CY, Liu M, Wang SY, Song XQ, Cui YW (2004a) Nitrite accumulation by aeration controlled in sequenc- ing batch reactors treating domestic wastewater. Water Sci Technol 50(10):35-43

Peng YZ, Li YZ, Peng CY, Wang SY (2004b) Nitrogen removal from pharmaceutical manufacturing wastewater with high concentration of ammonia and free ammonia via partial nitrification and denitrification. Water Sci Technol 50(6):31-36

Peng YZ, Song XQ, Peng CY, Li J, Chen Y (2004c) Biological nitrogen removal in SBR bypassing nitrate generation accomplished by chlorination and aeration time control. Water Sci Technol 49(5/6):295-300

Peng YZ, Zhu GB, Wang SY, Yu DS, Cui YW, Meng XS (2005) Pilotscale studies on biological treatment of hypersaline wastewater at low temperature. Water Sci Technol 52(10-11):129-137

Philips S, Laanbrock HJ, Verstraete W (2002) Origin, causes and effects of increased nitrite concentrations in aquatic environments. Reviews in Environmental Science and Bio/Technology 1:115-141

Picioreanu C, van Loosdrecht MCM, Heijnen JJ (1997) Modelling of the effect of oxygen concentration on nitrite accumulation in a biofilm airlift suspension reactor. Water Sci Technol 36:147-156

Pollice A, Tandoi V, Lestingi C (2002a) Influence of aeration and sludge retention time on ammonium oxidation to nitrite and nitrate. Water Res 36(10):2541-2546

Pollice A, Valter T, Carmela L (2002b) Influence of aeration and sludge retention time on ammonium oxidation to nitrite and nitrate. Water Res 36:2541-2546

Radajewski S, Webster G, Reay DS, Morris SA, Ineson Teske A, Alm E, Regan JM, Toze S, Rittmann BE, Stahl DA (1994) Evolutionary relationships among ammonia- and nitrite-oxidizing bacteria. J Bacteriol 176(21):6623-6630

Regan JM, Harrington GW, Noguera DR (2002) Ammonia- and nitrite-oxidizing bacterial communities in a pilot scale chloraminated drinking water distribution system. Appl Environ Microbiol 68(1):73-81

Rottenberg H (1990) Decoupling of oxidative phosphorylation and photo-phosphorylation. Biochim Biophys Acta 1018:1-17

Ruiz G, Jeison D, Chamy R (2003) Nitrification with high nitrite accumulation for the treatment of wastewater with high ammonia concentration. Water Res 37(6):1371-1377

Sijbesma WFH, Almeida JS, Reis MAM, Santos H (1996) Uncoupling effect of nitrite during denitrification by Pseudomonas fluorescens: an in vivo 31P-NMR study. Biotechnol Bioeng 52:176-182

Sliegrist H, Reithaar S, Lais P (1998) Nitrogen loss in a nitrifying rotating contactor treating ammonium rich leachate without organic carbon. Water Sci Technol 37(4-5):589-591

Stein LY, Arp DJ (1998) Loss of ammonia monooxygenase activity in Nitrosomonas europaea upon exposure to nitrite. Appl Environ Microbiol 64(10):4098-4102

STOWA (1995) Treatment of nitrogen rich return flows of sewage treatment plants. Evaluation of Dutch pilot plant research projects (in Dutch). STOWA report, pp 95-08

Stüven R, Vollmer M, Bock E (1992) The impact of organic matter on nitric oxide formation by Nitrosomonaseuropaea. Arch Microbiol 158:39-44

Surmacz-Gorska J, Cichon A, Miksch K (1997) Nitrogen removal from wastewater with high ammonia nitrogen concentration via shorter nitrification and denitrification. Water Sci Technol 36 (10): $73-78$

Teske A, Alm E, Regan JM, Toze S, Rittmann BE, Stahl DA (1994) Evolutionary relationships among ammonia- and nitrite-oxidizing bacteria. J Bacteriol 176(21):6623-6630

Timothy AH, Edward FD (1996) Comparative analysis of nitrifying bacteria associated with freshwater and marine aquaria. Appl Environ Microbiol (62):2888-2896

Tonkovic Z (1998) Nitrite accumulation at the Mornington sewage treatment plant-causes and significance (pp 165-172). 19th 
Biennial International Conference, Water Quality International 1998. IAWQ, Vancouver, Canada

Turk O, Mavinic DS (1987) Benefits of using selective inhibition to remove nitrogen from highly nitrogenous wastes. Environ Technol Lett 8:419-426

van Dongen U, Jetten MSM, van Loosdrecht MCM (2001) The SHARON-ANAMMOX process for treatment of ammonium rich wastewater. Water Sci Technol 44:53-60

van Kempen R, Mulder JW, Uijterllnde CA, van Loosdrecht MCM (2001) Overview: full scale experience of the SHARON process for treatment of rejection water of digested sludge dewatering. Water Sci Technol 44:145-152

van Rijn J, Tal Y, Barak Y (1996) Influence of volatile fatty acids on nitrite accumulation by a Pseudomonas stutzeri strain isolated from a denitrifying fluidized bed reactor. Environ Microbiol 62:2615-2620

Verstraete W, Philips S (1998) Nitrification-denitrification processes and technologies in new contexts. Environ Pollut 102 (S1):717-726

Wang SY, Gao DW, Peng YZ, Wang P, Yang Q (2004) Nitrificationdenitrification via nitrite for nitrogen removal from high nitrogen soybean wastewater with on-line fuzzy control. Water Sci Technol 49(5-6):121-127

Wheaton FW, Hochheimer JN, Kaiser GE, Kronos MJ, Libey GS, Easter CC (1994) Nitrification filter principles. In: Timmons MB, Losordo TM (eds) Aquaculture water reuse systems: engineering design and management. Elsevier, Amsterdam, pp 101-126
Wild D, Von Schulthess R, Gujer W (1995) Structured modeling of denitrification intermediates. Water Sci Technol 31:45-54

Wong-Chong GM, Loehr RC (1978) Kinetics of microbial nitrification: nitrite-nitrogen oxidation. Water Res 12:605-609

Wyffels S, van Hulle SWH, Boeckx P, Volcke EIP, van Cleemput O, van Rolleghem PA, Verstraete W (2004) Modelling and simulation of oxygen-limited partial nitritafition in a membrane-assisted bioreactor (MBR). Biotechnol Bioeng 86:531-542

Yang L, Alleman JE (1992) Investigation of batchwise nitrite build-up by an enriched nitrification culture. Water Sci Technol 26 (5-6):997-1005

Yang Q, Wang SY, Yang AM, Guo JH, Bo FY, Peng YZ (2006) Advanced nitrogen removal using pilot-scale SBR with intelligent control system built on three layer network. Acta Scientiae Circumstantiae 26(5):745-750

Yoo HS, Ann KH, Lee HJ, Lee KH, Kwak YJ, Song KG (1999) Nitrogen removal from synthetic wastewater by simultaneous nitrification and denitrification (SND) via nitrite in an intermittently aerated reactor. Water Res 33(1):145-154

Zeng W, Yang Q, Zhang SJ, Ma Y, Liu XH, Peng YZ (2006) Analysis of nitrifying bacteria in short-cut nitrification-denitrification processes by using Fish, PCR-DGGE and Cloning. Acta Scientiae Circumstantiae 26(5):734-739

Zhang SY, Wang JS, Jiang ZC, Chen MX (2000) Nitrite accumulation in an attapulgas clay biofilm reactor by fulvic acids. Bioresour Technol 73:91-93

Zheng P, Xu XL, Hu BL (2004) Novel theories and technologies of biological nitrogen removal. Science, Beijing 